\title{
Phytochemical screening and antibacterial activity of aqueous leaf extract of Punica granatum
}

\author{
Manoj Kumar ${ }^{1,2}$, Sukumar Dandapat ${ }^{2}$, Manoranjan Prasad Sinha ${ }^{2}$ \\ ${ }^{2}$ Department of Zoology, Ranchi University, Ranchi 834008, Jharkhand (India) \\ ${ }^{1}$ Address for correspondence: Department of Zoology, St. Xavier's College, Ranchi-834001, \\ Jharkhand (India)
}

\begin{abstract}
In the present study the leaves of Punica granatum were subjected to phytochemical screening and the impact of the leaf extract of Punica granatum was tested against Bacillus subtilis, Staphylococcus aureus and Salmonella typhi. The phytochemical analysis revealed the presence of various phytochemicals such as alkaloids, tannins, phenols, flavonoid and saponins.

Agar disk diffusion method was employed to test the antibacterial activity and the result showed that the aquesous leaf extract of Punica granatum showed $100 \%$ inhibition against all the tested bacteria at varying concentration of extract. The Minimum Inhbitory Concentration (MIC) of Punica granatum aqueous leaf extract that showed $100 \%$ inhibition was $0.36 \mathrm{mg} / \mathrm{ml}$, $0.13 \mathrm{mg} / \mathrm{ml}$ and $0.13 \mathrm{mg} / \mathrm{ml}$ in case of Bacullus subtilis, Staphylococcus aureus and Salmonella typhi respectively.
\end{abstract}

Key words: Punica granatum, Salmonella typhi, Staphylococcus aureus, Bacillus subtilis, MIC.

\section{Introduction}

Natural products are the source of synthetic and traditional medicine. Phytochemicals are compounds occurring naturally in plants. The use of plants and plant products as medicines could be traced as far back as beginning of human civilization. Plant extracts and compounds derived from plants are in use as drug from the ancient times [1]. The Indian subcontinent has a rich flora of various plants used in traditional medical treatments [2].

These plants contain different bioactive ingredients used to cure disease or relieve pain [3].

Punica granatum L., commonly known as pomegranate, is a fruit bearing deciduous shrub or small tree, native to Asia and belongs to family Lathraceae (Altuner, 2011) [4]. the leaves are shiny and about 7.6 $\mathrm{cm}$ long [5]. Different parts of plants such as leaves, bark, and fruit have medicinal significance [6]. Punica granatum has been used as traditional medicine in many countries for the treatment of dysentery, diarrhoea, helminthiasis, acidosis, hemorrhage etc. [7]. Numerous phytochemical constituents have been reported to be present in different parts of the Punica granatum plant, which makes it medicinally important.

Owing to the above apprehensions the present study was undertaken to screen the phytochemical constituents and antimicrobial activity of aqueous leaf extract of Punica granatum.

\section{Materials and Methods}

PLANT MATERIALS: the fresh tender leaves of Punica granatum was collected. The leaves were washed with deionised water and disinfected with $0.1 \%$ $\mathrm{HgCl}_{2}$ solution for $5 \mathrm{~min}$ and dried in shade away from light for 15 days and ground to fine powder using electrical grinder and sieved [8,9]

PREPARATION OF PLANT EXTRACT: the fine powder of Punica granatum was made into thimble for loading in Soxhlet apparatus and extraction was done continuously for 72 hours. The extract thus obtained was concentrated under vacuum rotary evaporator and extracts were kept in desiccators until used [10, 11]

PHYTOCHEMICAL

SCREENING: phytochemical screening 
were conducted in Punica granatum leaf extract according to previous published standards $[12,13]$

ANTIBACTERIAL ANALYSIS:

The organisms namely

- Staphylococcus aureus

- Bacillus subtilis

- Salmonella typhi

Were used during the present experiment and were procured from Hi-media. These organisms are potential causative agents for different diseases.

AGAR DISC DIFFUSION METHOD: Initially, the stock cultures of bacteria were revived by inoculating in broth media and grown at $37{ }^{\circ} \mathrm{C}$ for $48 \mathrm{hrs}$. The agar plates of the above media were prepared and wells were made in plate each plate was inoculated with $18 \mathrm{~h}$ hold cultures $(100 \mu, 104 \mathrm{CFU}$ and spread evenly on the plate. After 20 min, the wells were filled with different concentrations of samples. The control wells were filled with Gentamycin along with solvent. All the plates were incubated at $37^{\circ} \mathrm{C}$ for $24 \mathrm{~h}$ and the diameter of Zone of Inhibition (ZOI) were noted [14].

MEDIA USED: peptone - 10g, $\mathrm{NaCl}-$ $10 \mathrm{~g}$ and Yeast extract $5 \mathrm{~g}$, agar $-20 \mathrm{~g}$ in 1000 $\mathrm{ml}$ of distilled water.

\section{Results and Discussion PHYTOCHEMICAL}

SCREENING: the results of phytochemical screening is presented in Figure 1.. The results showed the presence of various phytochemicals such as alkaloid, flavonoid, saponin, tannin and phenol. The phytochemicals revealed during the phytochemical screening showed lowest concentration of alkaloid $(3.07 \pm 1.0 \mathrm{mg} / \mathrm{ml})$ and highest content of flavonoids (81.16 \pm $0.36 \mathrm{mg} / \mathrm{ml})$. According to Kumar et al. (2015) [10] the medicinal properties of the plants are due to the presence of the secondary metabolites (alkaloids, phenols etc.) in different parts. The phenols posses redox properties and thus impart antioxidant properties to the plants in which they are present [10]. Tannins, alkaloids, saponins and flavonoids have been found to be active antibacterial agents [15]. Thus taking into consideration the phytochemicals present in the leaf extract, Punica granatum leaf extract appears to be an effective potent antimicrobial agent.

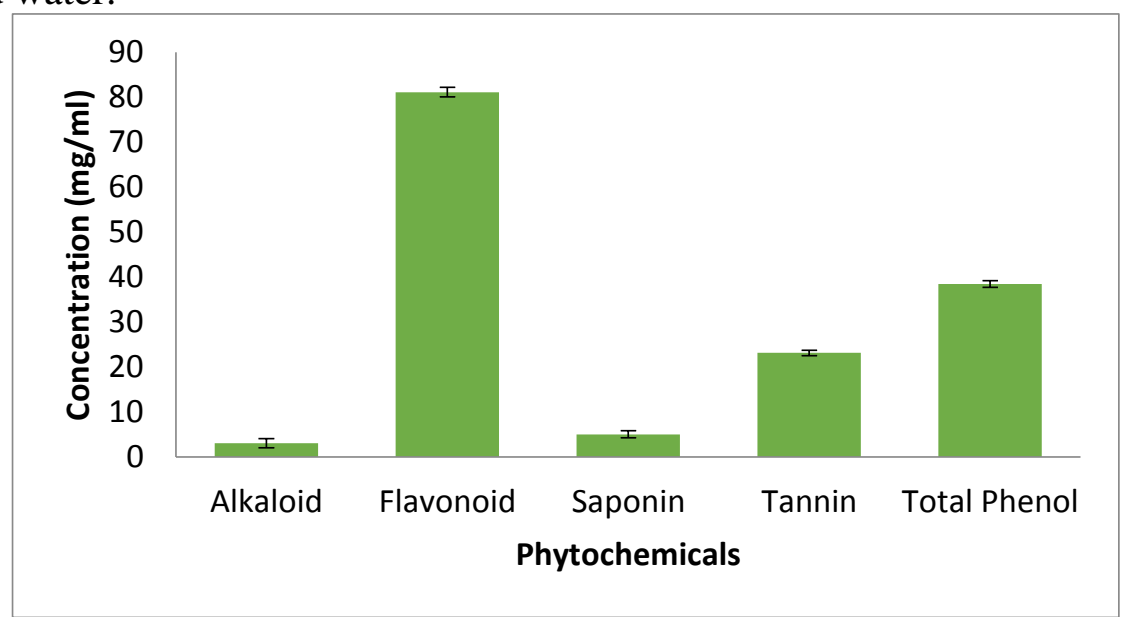

Figure 1: Results of Phytochemical screening of aqueous leaf extract of Punica granatum

ANTIBACTERIAL ANALYSIS: The antibacterial activity of Punica granatum aqueous leaf extract against Staphylococcus aureus, Bacillus subtilis and Salmonella typhi was determined using the agar disk diccusion method. The results of antibacterial screening, the agar plates showing the zone of inhibition (ZOI) of aqueous leaf extract of Punica granatum is presented in figure 2 , and the numerical value of the $\mathrm{ZOI}$ is presented as table 1. 
Table 1: Showing Zone of inhibition (ZOI) in mm and Minimum inhibitory concentration (MIC) against tested microbes

\begin{tabular}{|c|c|c|c|c|}
\hline \multirow{2}{*}{ Bacteria } & \multicolumn{3}{|c|}{ Concentration of extract $(\mathrm{mg} / \mathrm{ml})$} & \multirow{2}{*}{ MIC $(\mathrm{mg} / \mathrm{ml})$} \\
\cline { 2 - 5 } & $0.13 \mathrm{mg} / \mathrm{ml}$ & $0.36 \mathrm{mg} / \mathrm{ml}$ & $0.612 \mathrm{mg} / \mathrm{ml}$ & $0.36 \mathrm{mg}$ \\
\hline Bacillus subtilis & $\mathrm{ND}$ & 3 & 5 & $0.13 \mathrm{mg}$ \\
\hline Staphylococcus aureus & 2.5 & 6 & 10 & $0.13 \mathrm{mg}$ \\
\hline Salmonella typhi & 4.6 & 8.0 & 14.0 & \\
\hline
\end{tabular}

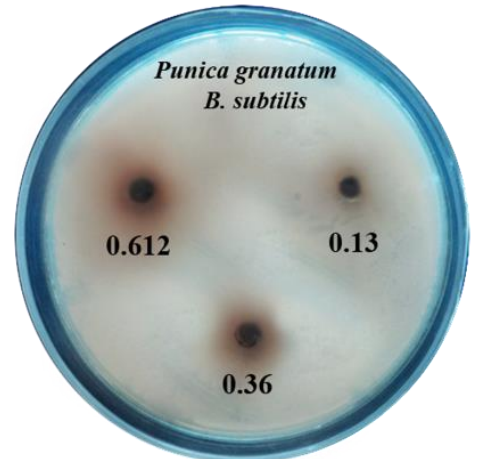

1(a)

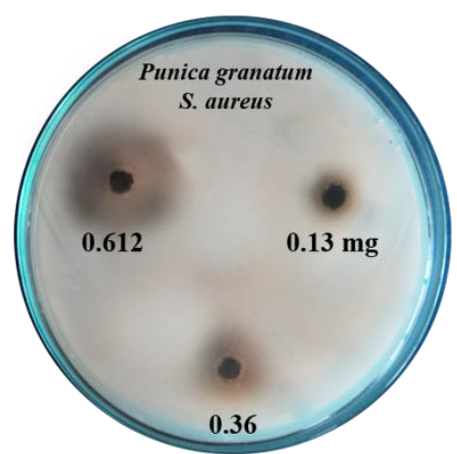

1(b)

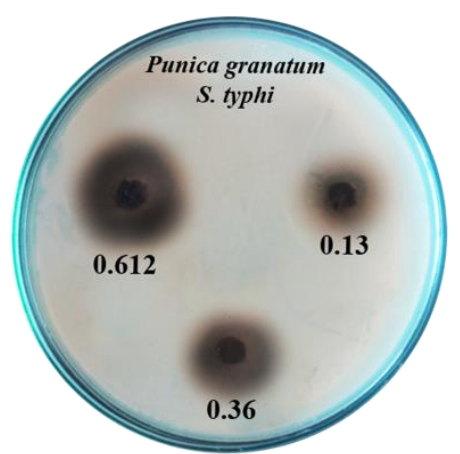

1(c)

Figure 2: Agar plates showing the Zone of inhibition (ZOI) of aqueous leaf extract of Punica granatum against tested microbes

Several phytochemicals have been known to possess antimicrobial properties. Tannins, alkaloids, saponins, flavonoids and sterols have been found to inhibit the growth of Salmonella typhi [14]. Middleton and Kandaswami (1994) [17] showed that flavonoids inhibit several enzymes, chelate certain metal cation, affects protein phorphorylation. Smith (1996) [18]concluded that flavonoids interpose several membrane linked processes. Tannins form irreversible complexes with prolene rich protein resulting in inhibition of cell synthesis in bacteria $[11,16]$. The leaf extract of Punica granatum was found effective against all the test bacteria. The MIC (minimum inhibitory concentration; the concentration of plant leaf extract showing $100 \%$ inhibition) of Punica granatum aqueous leaf extract in case of $B$. subtilis, $S$. aureus and $S$. typhi were found to be 0.36 $\mathrm{mg} / \mathrm{ml}, \quad 0.13 \mathrm{mg} / \mathrm{ml}$ and $0.13 \mathrm{mg} / \mathrm{ml}$ respectively. S. aureus is a gram +ve bacteria found frequently in human respiratory tract and on the skin. It is common cause of skin infections (eg. Boils), respiratory diseases (eg. Sunusitis), and food poisoning. $B$. subtilis is a gram +ve bacteria, found in gastrointestinal tract of ruminants and humans. It is also known to cause diseases in several immunocompromised patients. $S$. typhi causes typhoid fever, paratyphoid fever in humans.

The obtained results showed that the aqueous leaf extract of Punica granatum was effective as and antibacterial agent against tested bacteria (Bacillus subtilis, Staphylococcus aureus and Salmonella typhi). The demonstration of antibacterial activity of aqueous leaf extract of Punica granatum is indeed a promising development, which will help to discover new chemical classes (Medicines).

\section{References}

1. Kamal, A. and Khan, M. M. R. (2014), Phytochemical evaluation of some medicinal plants. Indian Journal of Plant Sciences 3(4): $5-8$.

2. Ballabh, B. and Chaurasia, O. P. (2007), Traditional medicinal plants of cold desert Ladakh - used in treatment of cold, cough 
and fever. Journal of Ethnopharmacology 112(2), $341-349$.

3. Okigbo, R. N., Eme U. E. and Ogbogu, S. (2008), Biodiversity and conservation of medicinal and aromatic plants in Africa, Biotechnology and molecular biology reviews 3(6): $127-134$.

4. Altuner, E. M. (2011), Investigation of antimicrobial activity of Punica granatum L. fruit peel ash used for protection against skin infections as folk remedies especially after maile circumcision, African Journal of Microbial Research 5(20): 3339 - 3342.

5. Qnais, E. Y., Elokda, A. S., Abu Ghalyun Y. Y. and Abdulla F. A. (2007), Antidiarrheal activity of aqueous extract of Punica granatum (pomegranate) peels, Pharm, Biol., 49(9), 715 - 720.

6. Arun N. and Singh, D. P. (2012), Punica granatum: a review on pharmacological and therapeutic properties, IJPSR 3(5) 1240 1245.

7. Choi J.G., Kang O.H., Lee Y.S., Chae H.S., Oh Y.C., Brice O.O., Kim M.S., Sohn D.H., Kim H.S., Park H., Shin D.W., Rho J.R. and Kwon D.Y. (2011), In vitro and in vivo antibacterial activity of Punica granatum peel ethanol extract against Salmonella, Evid. Based Complement, Alternative Medicine $1-8$.

8. Kumar, M., Dandapat, S. and Sinha, M. P. (2015), Hepatoprotective activity of Adhatoda vasica and Vitex negundo leaf extracts against Carbon Tetrachloride induced Hepatotoxicity in Rats, Advances in Biological Research 9(4): 242 - 246.

9. Dandapat, S., Kumar, M., Kumar A. and Sinha, M. P. (2013), Antipathogenic efficacy of methanolic leaf extract of Cinnamomum tamala (Buch.-Ham.) and Aegle marmelos (L.) with their nutritional potentiality, The Bioscan 8(2): 635 - 641 .

10. Kumar, M., Dandapat, S. and Sinha, M. P. (2015), Phytochemical analysis and growth inhibitory impact of Swertia chirayita aqueous leaf extract against some human pathogens, World Journal of Zoology 10(3): $188-190$.

11. Dandapat, S., Kumar, M. and Sinha, M.

P. (2014), Pharmacological and
Phytochemical Screening of Aegle marmelos (L.) and Cinnamomum tamala (Buch. Ham.) leaves for therapeutic efficacy, Middle-East Journal of Scientific Research 22(5): $326-632$.

12. Kumar, M., Dandapat, S., Kumar, A. and Sinha, M. P. (2013), Growth Inhibitory impact of Adhatoda vasica and Vitex negundo on some human pathogens, The Ecoscan Special issue(4): 241 - 246.

13. Kumar, A., Kumar, M., Dandapat, S. and Sinha, M. P. (2013), Antioxidant Activity and Pharmacological Screening of Tinospora cordifolia (Thunb.), The Bioscan 8(2): 689 693.

14. Kumar, M., Dandapat, S., Kumar, A. and Sinha, M. P. (2013), Anti-typhoid activity of Adhatoda vasica and Vitex negundo, Persian Gulf Crop Protection 2(3): 64 - 75.

15. Kennedy, D. O. and E. L. Withtman (2011), Herbal extracts and phytochemicals: plant secondary metabolites and enhancements of human brain function. Adv. Nutri., 2: $32-50$

16. Mamtha, B., Kavitha, K., Srinivasan, K. K. and Shivananda, P. G. (2004), An in-vitro study of the effect of centellaasiatica (Indian pennywort) on enteric pathogens, Indian Journal of Pharmacology 36(1): 41.

17. Middleton, Jr, E. and C. Kandaswami (1994), the flavonoids, advances in research science, London: Chapman and Hall, PP: 6199-6652.

18. Smith, C. J. (1996), Accumulation of phytoalexins: defence mechanism and stimulus response system. New phytology, 132(1): $1-45$. 